\title{
Pengaruh Komunikasi Internal terhadap Etos Kerja Pegawai di PPPAUD dan Dikmas Jawa Tengah
}

\author{
Rini Setyoningrum ${ }^{\bowtie}$, Tri Suminar
}

Jurusan Pendidikan Luar Sekolah FIP Universitas Negeri Semarang

\section{Info Artikel}

\section{Sejarah Artikel:}

Diterima Maret 2017

Disetujui Mei 2017

Dipublikasikan Juni 2017

\section{Keywords:}

internal communication; work ethos

\begin{abstract}
Abstrak
Permasalahan yang dikaji dalam penelitian ini adalah adakah pengaruh komunikasi internal terhadap etos kerja pegawai PP-PAUD dan Dikmas Jawa Tengah dengan besaran pengaruhnya. Penelitian menggunakan pendekatan kuantitatif dengan metode survei. Populasi sebanyak 114 orang. Sampel penelitian berjumlah 53 orang, dengan teknik cluster random sampling. Terdapat dua variabel, yaitu Komunikasi Internal (X) dan Etos Kerja (Y). Analisis menggunakan regresi linier sederhana. Bentuk persamaan regresi adalah $\mathrm{Y}=29,122+0,409 \mathrm{X}$. Nilai Sig. sebesar $0,002<0,05$ maka $\mathrm{H}_{0}$ ditolak yang berbunyi "Ada pengaruh signifikan antara komunikasi internal terhadap etos kerja pegawai PP-PAUD dan Dikmas Jawa Tengah". Adapun sumbangan pengaruhnya sebesar $16,9 \%$.
\end{abstract}

\section{Abstract}

The problem studied in this research is whether there is influence of internal communication to work ethic of PP-PAUD and Dikmas employee of Central Java with its influence magnitude. The research used quantitative approach with survey method. The population of 114 people. The sample of research is 53 people, with cluster random sampling technique. There are two variables, namely Internal Communication $(X)$ and Working Ethos $(Y)$. The analysis used simple linear regression. The form of regression equation is $Y=29.122+$ $0.409 X$. Sig value of $0.002<0.05$ then $H 0$ rejected which reads "There is significant influence between internal communication to work ethic of employees of PP-PAUD and Dikmas of Central Java". The contribution of the influence of $16.9 \%$.

Alamat korespondensi:

E-mail: dedekrini@gmail.com 


\section{PENDAHULUAN}

Sumber daya manusia (SDM) merupakan faktor sentral dalam suatu lembaga. Apapun bentuk dan tujuannya, suatu lembaga didirikan berdasarkan visi untuk kepentingan bersama, serta dalam pelaksanaan misinya dikelola dan diurus oleh manusia. Tenaga kerja atau pegawai merupakan sumber yang paling berharga di dalam lembaga. Tanpa adanya tenaga kerja yang berkualitas sulit tujuan lembaga dapat tercapai dengan baik. Organisasi dilakukan dalam suatu sistem yang terdiri daripada aktivitas-aktivitas yang dilakukan secara teratur dan berulang-ulang oleh sekelompok orang untuk mencapai tujuan bersama. Untuk mencapai tujuan tersebut, sebuah organisasi harus didukung oleh sumber-sumber daya yang berkualitas baik berwujud material, modal maupun manusianya.

Sumber daya manusia dalam organisasi lembaga memiliki peranan yang sangat penting. Dimana sumber daya manusia diperlukan untuk pencapaian tujuan lembaga yang optimal. Pencapaian tujuan tersebut pada dasarnya manusia saling membutuhkan antara satu dengan yang lainnya. Manusia sebagai mahluk sosial tidak dapat terlepas dari adanya komunikasi, maka dengan adanya komunikasi manusia dapat saling berhubungan antara satu dengan lainnya. Komunikasi merupakan suatu kesatuan yang tidak dapat dipisahkan dalam sebuah lembaga. Penggunaan komunikasi yang baik memungkinkan semua pekerjaan berjalan sesuai dengan apa yang diharapkan.

Menurut (Arni, 2007:24), "organisasi merupakan suatu sistem, mengkoordinasi aktivitas dan mencapai tujuan bersama atau tujuan umum". Dikatakan merupakan suatu sistem karena organisasi itu terdiri dari berbagai bagian yang saling tergantung sama lain. Bila satu bagian terganggu maka akan ikut berpengaruh pada bagian lain. Komunikasi merupakan aktivitas dasar manusia, dengan komunikasi manusia dapat saling berhubungan satu sama lain. Komunikasi merupakan urat nadinya sebuah lembaga. Komunikasi yang efektif penting bagi lembaga, karena dengan adanya komunikasi yang baik dan efektif memungkinkan semua pekerjaan berjalan sesuai harapan, berjalan lancar dan hasil baik dalam mencapai tujuannya. Sehingga apabila komunikasi dalam organisasi tersebut tidak berjalan efektif, maka mekanisme organisasi akan terganggu.

Menurut Danisworo \& Tanjung (2004:23), "di dalam perjalanan organisasi di sebuah lembaga haruslah memegang prinsip komunikasi". Jika terdapat masalah baik masalah dari dalam maupun luar lembaga, jangan sampai tidak ada komunikasi karena suasana tanpa komunikasi akan lebih memperburuk keadaan. Sehingga komunikasi sangat diperlukan didalam pengelolaan organisasi di sebuah lembaga. Semua lembaga memerlukan informasi untuk tetap berlangsung, tanpa informasi lembaga tidak dapat berjalan. Dengan adanya informasi bahan mentah dapat diolah menjadi hasil produksi yang dapat dimanfaatkan oleh manusia. Begitu juga sebaliknya dengan tidak adanya informasi, suatu lembaga dapat macet atau mati sama sekali. Untuk mendapatkan informasi adalah melalui proses komunikasi, sehingga tanpa komunikasi tidak mungkin mendapat informasi. Komunikasi memegang peranan penting dalam lembaga untuk mendapatkan informasi yang dibutuhkan, informasi yang dibutuhkan ini baik dari dalam lembaga sendiri maupun dari luar lembaga.

Komunikasi dalam sebuah lembaga khususnya dan umumnya terjadi dalam dua konteks, yaitu komunikasi yang terjadi didalam (internal communication) dan komunikasi yang terjadi diluar (external communication). Komunikasi internal merupakan komunikasi yang terjadi di dalam lingkungan lembaga. Komunikasi ini bisa terjadi antara pegawai dengan pegawai, pegawai dengan pemimpin, dan pemimpin dengan pemimpin. Komunikasi ini terjadi karena terdapat sebuah struktur dalam organisasi. Tujuannya untuk meningkatkan kinerja SDM dalam lembaga. Biasanya terjadi proses pertukaran informasi di antara struktur organisasi.

Komunikasi internal baik secara vertikal, horisontal, maupun diagonal sering terjadi kesulitan yang menyebabkan terjadinya 
ketidaklancaran komunikasi atau dengan kata lain terjadi miss communication. Kesulitan ini terjadi dikarenakan adanya kesalahpahaman, adanya sifat psikologis seperti egois, kurangnya keterbukaan antar pegawai, adanya perasaan tertekan dan sebagainya, sehingga menyebabkan komunikasi tidak efektif dan pada akhirnya tujuan sebuah lembaga pun sulit untuk tercapai.

Berdasarkan penelitian dari Setiadi \& sitohang (2013) menyatakan bahwa salah satu faktor yang berpengaruh terhadap kerja pegawai adalah komunikasi internal. Jika terjadi komunikasi yang harmonis antar pegawai maupun pegawai dengan pemimpin maka kinerja individu pegawai maupun kinerja lembaga akan meningkat. Komunikasi sangatlah penting, terutama komunikasi internal yang berperan penting terhadap berjalannya suatu lembaga. Karena komunikasi internal adalah proses penyampaian pesan-pesan yang berlangsung antar anggota lembaga yaitu antar pegawai maupun antara pegawai dengan pemimpin. Dibutuhkan komunikasi yang harmonis agar lembaga dapat berjalan lancar dan kinerja pegawai dapat ditingkatkan.

Penggunaan komunikasi harmonis dibutuhkan agar lembaga dapat berjalan lancar dan kinerja pegawai dapat ditingkatkan, sehingga, dapat meningkatkan etos kerja para pegawai karena komunikasi berhubungan dengan keseluruhan proses pembinaan perilaku manusia dalam lembaga. Etos kerja dalam lembaga dapat mempengaruhi hasil kerja dan pencapaian tujuan komunikasi dan hubungan kerja yang terjadi pada lembaga yang berkaitan dengan pelaksanakan pekerjaannya. Komunikasi efektif dapat mencapai saling pengertian antara pegawai dengan pimpinan ataupun antara pegawai dengan pegawai, sehingga terbentuk kondisi sosial yang dapat memotivasi pegawai untuk meningkatkan hasil kerjanya.

Komunikasi internal merupakan hal penting dalam dunia kerja, karena pada dasarnya komunikasi merupakan kebutuhan dasar manusia sebagai makhluk sosial. Manusia hidup dengan berkomunikasi, sehingga dapat mentransfer informasi terhadap diri sendiri maupun terhadap orang lain. Begitu pula di dunia kerja dalam meningkatkan etos kerja, komunikasi sangatlah penting khususnya komunikasi internal atau komunikasi yang terjadi di dalam lembaga. Dalam berkomunikasi juga memiliki berbagai cara atau teknik dalam penyampaian informasi agar terhindar dari "miss communication" atau ketidaklarasan dalam berkomunikasi. Dengan teknik komunikasi yang sesuai, penyampaian komunikasi antar pegawai ataupun pemimpin dengan pegawai yang sesuai dengan teknik komunikasi atau dengan komunikasi yang efektif dapat meningkatkan etos kerja pegawai.

Etos kerja adalah totalitas kepribadian dirinya serta caranya mengekspresikan, memandang, meyakini dan memberikan makna ada sesuatu, yang mendorong dirinya untuk bertindak dan meraih amal yang optimal sehingga pola hubungan antara manusia dengan dirinya dan antara manusia dengan makhluk lainnya dapat terjalin dengan baik (Tasmara, 2002:25). Etos ini dikenal pula kata etika yang hampir mendekati pada pengertian akhlak atau nilai-nilai yang berkaitan dengan baik buruk moral sehingga dalam etos kerja tersebut terkandung gairah atau semangat yang amat kuat untuk mengerjakan sesuatu secara optimal lebih baik dan bahkan berupaya untuk mencapai kualitas kerja yang sesempurna mungkin.

Berdasarkan penelitian (Esthianingsih, 2012), bahwa kinerja seorang pendidik merupakan suatu kemampuan kerja yang diperlihatkan oleh seseorang pendidik untuk memperoleh hasil kerja yang optimal. Kinerja pendidik sangat diperlukan, pendidik sendiri itu merupakan tugas utama mendidik, mengajar, mengampu, menilai peserta didik. Kinerja atau etos dalam bekerja sangatlah penting, terutama kinerja pada seseorang pendidik atau pamong belajar dalam mempengaruhi atau mendidik, mengajar, mengampu, serta menilai peserta didiknya. Sehingga dibutuhkan sebuah kinerja atau etos kerja yang seoptimal mungkin..

Adapun komunikasi yang sering di gunakan pada lembaga PP-PAUD dan Dikmas (Pusat Pengembangan Pendidikan Anak Usia Dini dan Pendidikan Masyarakat) Jawa Tengah 
yaitu komunikasi ke bawah yang dilakukan pimpinan kepada bawahannya, berupa perintah, instruksi tugas dan informasi. Sedangkan komunikasi ke atas dari pegawai kepada pimpinan hanya sesekali dilakukan bila pegawai membutuhkan informasi dari pimpinan, hal ini disebabkan karena kurang beraninya pegawai dalam menyampaikan kritik dan saran kepada pimpinan. Kurang seringnya komunikasi antara pimpinan dan pegawai menyebabkan komunikasi kurang efektif. Kurang efektifnya komunikasi ini, dapat menimbulkan terjadinya hubungan kerja yang kurang baik, dan apabila hal ini dibiarkan maka kemungkinan dapat menimbulkan implikasi yang kurang baik terhadap etos kerja dan pada akhirnya akan membawa dampak negatif dalam merealisasikan tujuan lembaga. Oleh karenanya, penelitian ini berhipotesis adanya pengaruh komunikasi internal terhadap etos kerja pegawai di PPPAUD dan Dikmas Regional 2 Jawa Tengah.

\section{METODE}

Penelitian tentang pengaruh komunikasi internal terhadap etos kerja pegawai di PPPAUD dan Dikmas Jawa Tengah menggunakan metode penelitian kuantitatif dengan pendekatan survei. "Untuk mendapatkan data dari tempat tertentu yang alamiah (bukan buatan) tentang sebab dan hal yang mempengaruhi terjadinya sesuatu" ((Sugiyono, 2013:12). Penelitian ini menggunakan dua variabel yaitu variabel independent $(\mathrm{X})$ adalah Komunikasi Internal sedangakan variabel dependent $(\mathrm{Y})$ adalah Etos Kerja.

Populasi penelitian ini adalah seluruh pegawai di PP-PAUD dan Dikmas Jawa Tengah yang berjumlah 114 orang. Adapun perinciannya sebagaimana pada tabel 1 . Karena populasi yang ada bersifat heterogen menurut bagian-bagiannya, sampel ditetapkan dengan menggunakan teknik cluster random sampling, diperoleh sampel berjumlah 53 responden. Berdasarkan data yang ada pada PP-PAUD dan Dikmas Jawa Tengah, nilai masing-masing sampelnya sebagaimana tabel 2 .

Teknik pengumpulan data yang digunakan adalah metode angket/kuesioner dan dokumentasi. Kuesioner yang digunakan adalah kuesioner tertutup, yakni kuesioner yang sudah disediakan jawabannya sehingga responden tinggal memilih dan dijawab secara langsung oleh responden digunakan untuk mengumpulkan data dari responden mengenai komunikasi internal terhadap etos kerja pegawai. Serta menggunakan kuesioner dalam bentuk check list $(\sqrt{ })$ yaitu responden membubuhkan tanda check $(\sqrt{ })$ pada pilihan jawaban. Sedangkan metode dokumentasi digunakan untuk melengkapi data yang berhubungan dengan gambaran umum PPPAUD dan Dikmas Jawa Tengah yang berupa struktur organisasi, jumlah pegawai, dan sejarah lembaga tersebut.

Tabel 1. Daftar Perincian Populasi Penelitian

\begin{tabular}{clc} 
No & \multicolumn{1}{c}{ Posisi Pegawai } & Populasi \\
\hline 1. & $\begin{array}{l}\text { Kepala Pusat dan Kepala } \\
\text { Bidang }\end{array}$ & 6 \\
2. & $\begin{array}{l}\text { Subbag Tata Usaha } \\
\text { 3. }\end{array}$ & 33 \\
& $\begin{array}{l}\text { Pidang Pengembangan } \\
\text { Program dan Informasi }\end{array}$ & 12 \\
4. & $\begin{array}{l}\text { Bidang Pengembangan } \\
\text { Sumber Daya }\end{array}$ & 11 \\
5. Pamong Belajar & 52 \\
\multicolumn{1}{c}{ Jumlah } & $\mathbf{1 1 4}$ \\
\hline $\begin{array}{l}\text { Sumber: Data primer jumlah pegawai PP-PAUD dan Dikmas } \\
\text { Jawa Tengah. }\end{array}$
\end{tabular}

Tabel 2. Daftar Perincian Sampel Penelitian

\begin{tabular}{clc}
\hline No & \multicolumn{1}{c}{ Posisi Pegawai } & Sampel \\
\hline 1. & Kepala Pusat dan Kepala & 3 \\
Bidang & 15 \\
2. & Subbag Tata Usaha & \\
3. & Bidang Pengembangan & 6 \\
Program dan Informasi & \\
4. & Bidang Pengembangan & 5 \\
& Sumber Daya & 24 \\
5. & Pamong Belajar & $\mathbf{5 3}$ \\
& Jumlah &
\end{tabular}

Sumber: Data primer jumlah pegawai PP-PAUD dan Dikmas Jawa Tengah yang sudah diolah.

Dalam penelitian ini validitas yang digunakan adalah validitas internal, yakni validitas yang dicapai apabila terdapat 
kesesuaian antara bagian-bagian instrumen secara keseluruhan. Peneliti menggunakan analisis butir, dimana untuk menguji validitas setiap butir maka skor-skor yang ada pada tiap butir dikorelasikan dengan skor total dengan menggunakan program SPSS (Statistical Product and Service Solutions) Versi 17. Uji validitas penelitian ini menggunakan metode Pearson Correlation (Product Moment Pearson). Sedangkan uji reliabilitasnya karena instrumen yang akan digunakan berupa angket dengan skala 1-4, maka pengujian reliabilitasnya dengan menggunakan metode Cronbach Alpha dengan program SPSS 17.

Teknik pengolahan data menggunakan perhitungan komputasi program SPSS, yaitu suatu program komputer statistik yang mampu memproses data statistik secara cepat dan tepat, menjadi berbagai output yang dikehendaki para pengambil keputusan. Penelitian ini menggunakan metode kuantitatif dengan menggunakan teknik analisis regresi linier sederhana. Analisis data adalah kegiatan menghitung data agar dapat disajikan secara sistematis. Analisis data untuk penelitian kuantitatif bisa dilakukan secara manual dengan menghitung menggunakan rumus-rumus statistik atau menggunakan program bantu statistik seperti program SPSS.

Metode analisis data yang digunakan adalah teknik analisis deskriptif persentase, uji prasyarat analisis regresi, setelah prsyarat terpenuhi dan yang terakhir adalah analisis regresi linier sederhana. Teknik analisis deskriptif persentase, digunakan untuk mengkaji variabel yang ada dalam penelitian ini, yaitu variabel komunikasi internal dan variabel etos kerja. Uji prasyarat analisis regresi, dilakukan sebelum analisis regresi, harus memenuhi beberapa syarat antara lain: uji normalitas, digunakan untuk menguji data yang diperoleh berdistribusi normal atau tidak, dalam penelitian ini digunakan metode Kolmogorov-Smirnov $Z$ dengan kriteria penilaian uji normalitas data adalah apabila hasil nilai Signifikansi lebih besar dari pada 0,05 maka data tersebut berditribusi normal, sebaliknya apabila hasil nilai Signifikansi lebih kecil daripada 0,05 maka data tersebut tidak berditribusi normal; serta uji linieritas bertujuan untuk mengetahui apakah dua variabel yang akan dikenai prosedur analisis statistik korelasional menunjukan hubungan yang linier atau tidak dengan kriteria penilaian uji linieritas adalah apabila hasil nilai Signifikansi pada Linierity kurang dari pada 0,05 maka data tersebut berditribusi linier. Sebaliknya, apabila hasil nilai Signifikansi Linierity lebih besar dari pada 0,05 maka data tersebut tidak linier.

Analisis regresi linier sederhanadilakukan setelah syarat-syarat uji analisis regresi terpenuhi. Maka selanjutnya dapat dilakukan analisis regresi linier sederhana karena menggunakan dua variabel yaitu variabel Komunikasi Internal (X) dan variabel Etos Kerja $(\mathrm{Y})$. Analisis ini digunakan untuk menganalisis data penelitian tentang pengaruh komunikasi internal terhadap etos kerja pegawai PP-PAUD dan Dikmas Jawa Tengah. Setelah analisis regresi linier sederhana menggunakan program SPSS selanjutnya dapat menentukan persamaan regresi linier, uji hipotesis, dan koefesien determinasi.

\section{HASIL DAN PEMBAHASAN}

Penelitian dilaksanakan di Pusat Pengembangan Pendidikan Anak Usia Dini dan Pendidikan Masyarakat (PP-PAUD dan Dikmas) Jawa Tengah di bawah pengawasan Kementerian Pendidikan dan Kebudayaan (Kemendikbud). Lembaga ini berlokasi di Jalan Diponegoro no. 259 Ungaran kabupaten Semarang. Adapun penelitian ini di lokasi tersebut karena untuk mengetahui bagaimana peran komunikasi internal pada sebuah lembaga dalam mengembangkan kompetensi yang dimiliki oleh tenaga pendidik maupun tenaga kependidikan serta dalam meningkatkan kinerja pegawai tersebut maupun kinerja pada lembaga PP-PAUD dan Dikmas Jawa Tengah tersebut.

Dalam pelaksanaan penelitian ini terdapat beberapa faktor penghambat seperti dalam pengumpulan data menggunakan angket atau kuesioner dibutuhkan waktu cukup lama karena banyak pegawai yang sedang melaksanakan tugasnya di luar lapangan atau dinas ke luar 
kota sehingga harus menunggu beberapa hari untuk pengumpulan data tersebut. Namun beberapa faktor penghambat tersebut dapat teratasi dengan baik karena para pegawai atau responden dapat memberikan informasi dan data dengan baik.

Hasil penelitian ini merupakan hasil kajian lapangan tentang pengaruh komunikasi internal terhadap etos kerja pegawai di PPPAUD dan Dikmas Jawa Tengah. Setelah data terkumpul dilakukan analisis statistik melalui program SPSS.17 untuk mengetahui adakah pengaruh komunikasi internal terhadap etos kerja pegawai. Sebelum melakukan analisis statistik tersebut diatas dilakukan pengumpulan data di lapangan melalui kuesioner yang terlebih dahulu di ujicoba validitas dan reliablitas instrumen terhadap 20 responden diproleh hasil varibel $\mathrm{X}$ dan varibel $\mathrm{Y}$ dinyatakan valid dan reliabel. Setelah data dinyatakan valid dan reliabel maka selanjutnya dapat dilakukan analisis data.

Analisis data dalam penelitian ini diperoleh hasil perhitungan analisis deskriptif persentase pada tabel 3. Berdasarkan tabel 3 . menunjukkan bahwa $49,1 \%$ responden menyatakan komunikasi internal yang diterapkan pada lembaga PP-PAUD dan Dikmas Jawa Tengah sudah termasuk kategori baik, sedangkan sisanya $47,2 \%$ menyatakan sangat baik, 3,8\% menyatakan cukup baik dan hanya $0,0 \%$ dari responden yang menyatakan kurang baik.

Tabel 3. Distribusi Komunikasi Internal Pegawai

\begin{tabular}{cccc}
\hline Skor & Kategori & f & Presentase \\
\hline $30-36$ & Sangat Baik & 25 & $47,2 \%$ \\
$23-29$ & Baik & 26 & $49,1 \%$ \\
$16-22$ & Cukup Baik & 2 & $3,8 \%$ \\
$9-15$ & Kurang Baik & 0 & $0,0 \%$ \\
& Total & $\mathbf{5 3}$ & $\mathbf{1 0 0 , 0 \%}$ \\
\hline
\end{tabular}

Tabel 4. Hasil Analisis Deskriptif Persentase Tiap Sub Variabel Komunikasi Internal

\begin{tabular}{cccc}
\hline No & Sub Variabel & Persentase & Kategori \\
\hline 1. & Koumikasi Vertikal & $75,5 \%$ & Baik \\
2. & Koumikasi Horizontal & $60.4 \%$ & Baik \\
3. & Koumikasi Diagonal & $49,1 \%$ & Baik \\
4. & Koumikasi Informal & $56,6 \%$ & Baik \\
\hline
\end{tabular}

Tabel 5. Distribusi Etos Kerja Pegawai

\begin{tabular}{cccc}
\hline Skor & Kategori & f & Presentase \\
\hline $42-51$ & Sangat Baik & 27 & $50,9 \%$ \\
$32-41$ & Baik & 26 & $49,1 \%$ \\
$22-31$ & Cukup Baik & 0 & $0,0 \%$ \\
$12-21$ & Kurang Baik & 0 & $0,0 \%$ \\
& Total & $\mathbf{5 3}$ & $\mathbf{1 0 0 , 0 \%}$ \\
\hline
\end{tabular}



Secara lebih rinci gambaran tentang komunikasi internal pegawai pada lembaga PPPAUD dan Dikmas Jawa Tengah ditinjau dari tiap-tiap indikator yaitu komunikasi vertikal, komunikasi horizontal, komunikasi diagonal dan komunikasi informal, diperoleh hasil sebagaimana tabel 4. Berdasarkan tabel 4 diperoleh hasil bahwa sub variabel komunikasi internal yang meliputi komunikasi vertikal sebesar 75,5\% kategori baik, komunikasi horizontal $60,4 \%$ dalam kategori baik, komunikasi diagonal 49,1\% kategori baik dan komunikasi informal sebesar $56,6 \%$ kategori baik. Rata-rata dari sub variabel komunikasi internal sudah termasuk dalam kategori baik.

Hasil analisis deskriptif pada variabel etos kerja $(\mathrm{Y})$ diperoleh hasil seperti disajikan pada tabel 5 diperoleh hasil bahwa sebagian besar pegawai $(50,9 \%)$ termasuk dalam kategori sangat baik, sedangkan selebihnya yaitu $49,1 \%$ dalam kategori baik, serta $0,0 \%$ dalam kategori cukup baik dan kategori kurang baik. Ini berarti bahwa variabel komunikasi internal (X) pada lembaga PP-PAUD dan Dikmas Jawa Tengah termasuk dalam kategori baik, sedangkan untuk varibel etos kerja (Y) pegawainya sudah termasuk dalam kategori sangat baik.

Uji prasyarat analisis regresi seperti uji normalitas data dari hasil perhitungan diperoleh bahwa data komunikasi internal nilai Asymp. Sig. (2-tailed) sebesar 0,748 dan data etos kerja sebesar 0,643. Karena signifikansi lebih dari 0,05 jadi data komunikasi internal dan etos kerja dinyatakan berdistribusi normal. Sedangkan hasil uji linieritasnya diperoleh hasil bahwa Signifikansi pada Linierity sebesar $0,00<0,05$ jadi hubungan antara Komunikasi Internal dengan Etos Kerja dinyatakan linier.

Berdasarkan hasil perhitungan analisis regresi linier sederhana antara antara komunikasi internal terhadap etos kerja dengan menggunakan program SPSS 17, maka diperoleh seperti yang tertera pada tabel 6 .

Tabel 6. Hasil Output Analisis Regresi Linier (Corfficients)

Coefficients $^{\mathbf{a}}$

\begin{tabular}{|c|c|c|c|c|c|c|}
\hline & \multirow{3}{*}{ Model } & Unstan & ardized & \multicolumn{2}{|l|}{ Standardized } & \multirow{3}{*}{ Sig. } \\
\hline & & \multicolumn{2}{|c|}{ Coefficients } & Coefficients & $\mathrm{t}$ & \\
\hline & & B & Std. Error & Beta & & \\
\hline 1 & (Constant) & 29.122 & 3.784 & & 7.697 & .000 \\
\hline & $\begin{array}{l}\text { Komunikasi } \\
\text { Internal }\end{array}$ & .409 & .127 & .411 & 3.218 & .002 \\
\hline
\end{tabular}

a. Dependent Variable: Etos Kerja

Tabel 7. Hasil Output Analisis Regresi Linier (ANOVA)

\begin{tabular}{ccccccc}
\multicolumn{1}{c}{} & \multicolumn{5}{c}{ ANOVA $^{\mathbf{b}}$} \\
\hline \multirow{2}{*}{ Model } & $\begin{array}{c}\text { Sum of } \\
\text { Squares }\end{array}$ & df & $\begin{array}{c}\text { Mean } \\
\text { Square }\end{array}$ & F & \multirow{2}{*}{ Sig. } \\
\hline \multirow{2}{*}{1} & Regression & $\mathbf{1 6 4 . 6 4 7}$ & $\mathbf{1}$ & $\mathbf{1 6 4 . 6 4 7}$ & $\mathbf{1 0 . 3 5 6}$ & $\mathbf{. 0 0 2}^{\mathbf{a}}$ \\
& Residual & 810.825 & 51 & 15.899 & & \\
& Total & 975.472 & 52 & & & \\
\hline
\end{tabular}

a. Predictors: (Constant), Komunikasi Internal

b. Dependent Variable: Etos Kerja

Tabel 8. Hasil Output Analisis Koefisien Determinasi

Model Summary

\begin{tabular}{lllll}
\hline Model & R & R Square & Adjusted R & Std. Error of the \\
\hline
\end{tabular}




\begin{tabular}{ccccc}
\hline & & Square & Estimate \\
\hline 1 & $.411^{\mathrm{a}}$ & .169 & .152 & 3.987 \\
\hline
\end{tabular}

a. Predictors: (Constant), Komunikasi Internal

Tabel 6 didapatkan persamaan regresi linier sederhana yaitu $\mathrm{Y}^{\prime}=\mathrm{b} 0+\mathrm{b} 1 \mathrm{X}$. ( $\mathrm{Y}^{\prime}$ adalah variabel dependen yang diramalkan, b0 adalah konstanta, b1 adalah koefisien regresi, dan $\mathrm{X}$ adalah variabel independen). Nilai-nilai koefesien dapat dilihat pada output tabel Coefficients dan dimasukan pada persamaan $Y^{\prime}=29,122+0,409 X$ dengan makna dari persamaan yaitu konstanta sebesar 29,122 menyatakan bahwa, jika tidak ada variabel komunikasi internal, maka etos kerja sebesar 29,122; dan koefisien regresi X sebesar 0,409 menyatakan bahwa setiap penambahan satu point komunikasi internal akan meningkatkan etos kerja sebesar 0,409.

Pengaruh Komunikasi Internal terhadap Etos Kerja Pegawai melalui program SPSS 17 diperoleh pada tabel 7 dengan hasil perhitungan ANOVA tersebut dengan hasil perhitungan $\mathrm{F}$ sebesar 10,356 dan probability (Sig) 0,002 yang berarti lebih kecil dengan taraf signifikansi 0,05 atau Sig $0,002<0,05$, sehingga dapat disimpulkan keputusan bahwa $\mathrm{H}_{0}$ ditolak yang berbunyi "Ada pengaruh yang signifikan antara komunikasi internal terhadap etos kerja pegawai PP-PAUD dan Dikmas Jawa Tengah".

Harga koefisien determinasi digunakan untuk mengetahui besarnya pengaruh komunikasi internal terhadap etos kerja pegawai di PP-PAUD dan Dikmas Jawa Tengah. Konstribusi pengaruh variabel independen (Komunikasi Internal) terhadap variabel dependen (Etos Kerja) berdasarkan output tabel 8. Hasil output analisis koefisien determinasi dapat diketahui nilai $\mathrm{R}^{2}$ (R Square) adalah 0,169 . Jadi sumbangan pengaruh dari variabel independen (Komunikasi Internal) terhadap variabel dependen (Etos Kerja) pegawai di PPPAUD dan Dikmas Jawa Tengah adalah sebesar $16,9 \%$ sedangkan sisanya $83,1 \%$ dipengaruhi oleh variabel lain yang tidak tercakup dalam penelitian ini.

Bentuk pengaruh tersebut berarti apabila variabel independen (Komunikasi Internal) ditingkatkan maka akan diikuti pula dengan meningkatnya variabel dependen (Etos Kerja) pegawai di PP-PAUD dan Dikmas Jawa Tengah dan sebaliknya jika variabel independen (Komunikasi Internal) menurun maka akan diikuti dengan menurunya variabel dependen (Etos Kerja) pegawai.

"Komunikasi internal yaitu komunikasi yang dikirim kepada anggota organisasi dalam suatu organisasi atau instansi" (Arni, 2007:97). Dalam hal ini komunikasi adalah komunikasi antar pegawai yang ada di PP-PAUD dan Dikmas Jawa Tengah, yang terdiri dari komunikasi formal yang meliputi komunikasi vertikal (komunikasi ke bawah dan komunikasi ke atas), komunikasi horizontal, serta komunikasi diagonal maupun komunikasi antar pegawai secara komunikasi informal yaitu interaksi komunikasi yang bersifat humanis di luar substansi pekerjaan. Penelitian oleh (Femi, 2014), bahwa komunikasi yang buruk dapat mempengaruhi kerja pegawai. Oleh karena itu, lembaga harus secara teratur mengartikulasikan kebijakan, tujuan dan sasaran untuk meningkatkan kerja pegawai. Artinya, komunikasi merupakan sarana dan sumber daya yang dibutuhkan untuk melaksanakan tugas, peran dan hasil yang diharapkan oleh pegawai sehingga dapat menghasilkan kinerja yang baik. Berkomunikasi dengan efektif dan secara teratur untuk mendapatkan umpan balik atau informasi untuk mencegah kebingungan tentang pekerjaan sehingga dapat meningkatkan kerja pegawai dan meningkatkan produktivitas lembaga.

Lawrence D. Brennan (Effendy, 2013) mengemukakan bahwa komunikasi intenal adalah pertukaran gagasan di antara para administrator dan pegawai dari satu lembaga yang menyebabkan terwujudnya lembaga tersebut lengkap dengan struktur yang khas (organisasi) dan pertukaran gagasan secara horizontal, vertikal serta diagonal didalam lembaga yang menyebabkan pekerjaan berlangsung (operasi dan manajemen). Etos 
dibentuk oleh berbagai kebiasaan, pengaruh budaya, serta sistem nilai yang diyakininya. Dari kata etos ini, dikenal pula kata etika, etiket yang hampir mirip mendekati pada pengertian akhlak atau nilai-nilai yang berkaitan dengan baik buruk (moral). Sehingga dalam "etos tersebut tersandung gairah atau semangat yang amat kuat untuk mengerjakan secara optimal, lebih baik, dan bahkan berupaya untuk mencapai kualitas kerja yang sesempurna mungkin" (Tasmara, 2002:15).

Etos kerja merupakan totalitas kepribadian diri serta cara mengekspresikan, memandang, meyakini dan memberikan makna pada sesuatu, yang mendorong dirinya untuk bertindak dan meraih kinerja yang optimal. Sehingga dengan etos kerja pegawai yang baik dapat menimbulkan hubungan atau pola kerja yang baik pula antar pegawai. Etos kerja juga berhubungan dengan beberapa hal penting seperti kerja keras, produktivitas, kedisiplinan, efektifitas dan efesiensi, seta loyalitas terhadap pekerjaan atau tanggung jawab.

Hasil penelitian (Neill, 2016) mengungkap adanya pengaruh dari komunikasi internal terhadap kerja pegawai,

"While public relations practitioners have an influential role in the two areas of creating strategic communication plans and disseminating messages to employees, they have a lesser role in employee recruitment and orientation, which are critical stages in developing organizational identity and engagement among employees".

Pendapat tersebut juga terdukung oleh penelitian (Elving, 2005) yang penelitiannya mengungkap peran komunikasi dalam perubahan organisasi. Dijelaskan peran komunikasi selama perubahan organisasi atau lembaga dengan merefleksikan tujuan komunikasi internal dan kaitannya dengan perubahan lembaga. Perbedaan antara fungsi informatif komunikasi dan komunikasi untuk masyarakat. Model komunikasi tidak hanya berpengaruh pada kesiapan untuk perubahan, tetapi juga pada ketidakpastian. Demikian yang tertulis,

"In this paper I tried to explain the role of communication during organisational change by reflecting the goals of internal communication and discuss them in relation to organisational change. A distinction between the informative function of communication and communication as a mean to create a community was made. In the suggested model communication has not only an effect on readiness for change, but also on uncertainty."

Hal ini berarti bahwa komunikasi internal berpengaruh terhadap etos kerja. Adapun beberapa penelitian terdahulu yang mendukung pernyataan tersebut seperti yang diungkap oleh Wisudawati (2005) menunjukan bahwa ada pengaruh dari komunikasi internal terhadap semangat kerja di Dinas Pendidikan dan Kebudayaan Propinsi Jawa Tengah adalah sebesar 0,43 artinya 43,9\% keragaman variabel semangat kerja di Dinas Pendidikan dan Kebudayaan Propinsi Jawa Tengah disebabkan komunikasi intern atau komunikasi internal. Sedangkan sisanya sebesar 56,1\% dipengaruhi oleh variabel lain yang tidak diungkap di dalam penelitian. Kesimpulan penelitiannya membuktikan bahwa faktor komunikasi intern atau internal berpengaruh terhadap semangat kerja di Dinas Pendidikan dan Kebudayaan Propinsi Jawa Tengah atau kata lain yaitu ada pengaruh positif antara komunikasi intern terhadap semangat kerja pegawai pada Dinas Pendidikan dan Kebudayaan Propinsi Jawa Tengah.

Fitria (2007) dalam penelitiannya yang berjudul "Pengaruh Komunikasi AtasanBawahan terhadap Motivasi Kerja Pegawai Kementerian Negara Lingkungan Hidup". Di dalam penelitian ini pengaruh komunikasi atasan-bawahan terhadap motivasi kerja pegawai pada Kementerian Negara Lingkungan Hidup diperoleh hasil yang signifikan. Artinya bahwa komunikasi atasan-bawahan mempunyai pengaruh positif terhadap motivasi kerja pegawai Kementerian Negara Lingkungan Hidup sebesar 44,1\%, dan kedua variable mempunyai hubungan yang kuat sebesar 0,664. Sedangkan untuk 55,9\% komunikasi atasanbawahan dipengaruhi oleh faktor lain.

Penelitian lain, (Utomo, 2015) tentang "Pengaruh Komunikasi Internal Terhadap Efisiensi Kerja Pegawai Pada Pt. Ronalds 
Brothers Tour Dan Travel Di Samarinda". Dinyatakan bahwa komunikasi internal tidak berpengaruh signifikan terhadap efisiensi kerja pegawai pada PT. Ronalds Brothers Tour dan Travel di Samarinda. Hal ini dapat dilihat dari perbandingan taraf signifikansi Sig dengan $\alpha$. Sig yaitu $(0,487)>\alpha(0,05)$ dengan nilai regresi linier sederhana sebesar 0,078 dan nilai koefisien korelasi (R) sebesar 0,121 dalam kategori memiliki hubungan sangat rendah antara komunikasi internal terhadap efisiensi kerja. Nilai koefisien determinasi sebesar 0.015 atau $1,5 \%$ artinya variabel komunikasi internal memiliki pengaruh $1,5 \%$ terhadap efisiensi kerja dan $98,5 \%$ efisiensi kerja dipengaruhi oleh variabel lain.

Dari berbagai penelitian dapat diartikan bahwa tidak semua faktor komunikasi internal berpengaruh secara signifikan terhadap etos kerja pegawai, namun ada faktor lain juga yang mempengaruhi etos kerja pegawai. Sesuai dengan hasil penelitian ini bahwa adanya pengaruh komunikasi internal terhadap etos kerja, maka semakin baik kualitas komunikasi internal baik secara formal maupun informal pada pegawai akan berdampak baik pula untuk etos kerja pegawai. Sehingga pegawai dalam bekerja tidak terjadi miss communication atau penyampaian gagasan yang kurang tepat atau keliru yang dapat mengakibatkan berdampak buruk terhadap kinerja pegawai. Jika seumpama terjadi permasalahan pada kinerja pegawai di instansi tersebut maka akan sangat berdampak buruk untuk instansi khususnya dalam pelaksanaan tugasnya serta pencapaian visi di instansi PP-PAUD dan Dikmas Jawa Tengah tersebut.

\section{SIMPULAN}

Komunikasi internal pada lembaga PPPAUD dan Dikmas Jawa Tengah termasuk dalam kategori baik. Hal ini dapat dilihat pada hasil perhitungan analisis deskriptif persentase yaitu $49,1 \%$ responden menyatakan komunikasi internal sudah termasuk kategori baik, sedangkan sisanya $47,2 \%$ menyatakan sangat baik, 3,8\% menyatakan cukup baik dan hanya $0,0 \%$ dari responden yang menyatakan kurang baik. lebih rinci diperoleh hasil bahwa sub variabel komunikasi internal yang meliputi komunikasi vertikal sebesar 75,5\% kategori baik, komunikasi horizontal $60,4 \%$ dalam kategori baik, komunikasi diagonal $49,1 \%$ kategori baik dan komunikasi informal sebesar 56,6\% kategori baik. Sedangkan hasil analisis deskriptif pada variabel etos kerja $(\mathrm{Y})$ diperoleh hasil bahwa sebagian besar pegawai $(50,9 \%)$ termasuk dalam kategori sangat baik, sedangkan selebihnya yaitu $49,1 \%$ dalam kategori baik, serta 0,0\% dalam kategori cukup baik dan kategori kurang baik.

Ada pengaruh positif dan signifikan variabel independen (Komunikasi Internal) terhadap variabel dependen (Etos Kerja) pegawai di PP-PAUD dan Dikmas Jawa Tengah. Hal ini dapat dilihat pada pengujian hipotesis dengan analisis hasil perhitungan ANOVA diperoleh $F$ sebesar 10,356 dan probability (Sig) 0,002 yang berarti lebih kecil dengan taraf signifikansi 0,05 atau Sig 0,002< 0,05 , sehingga hipotesis $\mathrm{H}_{0}$ ditolak maka berbunyi "Ada pengaruh yang signifikan antara komunikasi internal terhadap etos kerja pegawai di PP-PAUD dan Dikmas Jawa Tengah".

Besarnya sumbangan pengaruh yang diberikan variabel independen (Komunikasi Internal) terhadap variabel dependen (Etos Kerja) pegawai di PP-PAUD dan Dikmas Jawa Tengah adalah sebesar $16,9 \%$ sedangkan sisanya sebesar $83,1 \%$ dipengaruhi oleh faktor lain yang tidak tercakup dalam penelitian ini.

Bagi pihak atasan atau pimpinan (pemimpin), agar bawahan atau pegawai tidak merasa segan untuk memberikan kritik kepada pimpinan, maka pimpinan hendaknya selalu menciptakan suasana harmonis dengan pegawainya, dengan cara selalu berkomunikasi dengan pegawai mengenai pekerjaan. Bagi para pegawai sendiri diharapkan untuk meningkatkan komunikasi dengan atasan atau pemimpinnya. Pegawai harus berani bertanya bila mengalami kesulitan kepada pemimpin, sehingga terjadi komunikasi timbal balik antara atasan dengan para pegawai. Selain itu komunikasi antara pegawai yang sudah baik juga perlu dipertahankan dan ditingkatkan agar terjadi pertukaran informasi yang baik berkaitan 
dengan pekerjaan di antara pegawai, sehingga apabila terjadi kesulitan kerja dapat diatasi secara bersama-sama. Bagi peneliti yang ingin melanjutkan penelitian ini sebaiknya ditambahkan lagi variabel lain sehingga akan melengkapi variabel yang memberikan konstribusi lebih besar terhadap etos kerja pegawai.

\section{DAFTAR PUSTAKA}

Arni, M. (2007). Komunikasi organisasi. Jakarta: Bumi Aksara.

Danisworo, S., \& Tanjung, H. (2004). Membuat tempat kerja fell at home: 7 prinsip suryo management. Jakarta: PT. Grasindo.

Effendy, O. U. (2013). Ilmu dan komunikasi: teori dan praktik. Bandung: PT. Remaja Rosdakarya.

Elving, W. J. (2005). The role of communication in organisational change. Corporate Communications An International Journal, 10(2), 129-138.

Esthianingsih, S. S. (2012). Kinerja pendidik dalam kegiatan pembelajaran kelompok bermain (KB) di pendidikan anak usia dini (PAUD) lab school Universitas Negeri Semarang (UNNES). Journal of Nonformal Education and Community Empowerment, 1(1), 2252-6331.

Femi, A. F. (2014). The impact of communication on workers' perfomance in selected organisation in Lagos State, Nigeria. IOSR Journal of Humanities and Social Sciense, 19(8), 75-82.

Fitria. (2007). Pengaruh komunikasi atasanbawahan terhadap motivasi kerja pegawai kementerian negara lingkungan hidup. Universitas Mercubuana.

Neill, M. S. (2016). The influence of employer branding in internal communication. Research Journal of the Institute for Public Relations, 3(1), 1-25.

Setiadi, A., \& Sitohang, S. (2013). Pengaruh Motivasi, lingungan kerja dan komunikasi intern terhadap kinerja karyawan UD. Rezeki Surabaya. Jurnal Ilmu \& Riset Manajemen, 2(11), 1-21.

Sugiyono. (2013). Metode penelitian pendidikan (pendekatan kuantitatif, kualitatif, dan $R \&$ D). Bandung: Alfabeta.

Tasmara, T. (2002). Membudayakan etos kerja islami. Jakarta: Gema Insani Press.

Utomo, I. Y. (2015). Pengaruh komunikasi internal terhadap efisiensi kerja pegawai pada PT. Ronalds Brothers Tour dan Travel di Samarinda. Jurnal Ilmu Administrasi Bisnis, 4(2), 491-505.

Wisudawati, A. M. (2005). Pengaruh komunikasi intern terhadap semangat kerja pegawai pada dinas pendidikan dan kebudayaan Propinsi Jawa Tengah. Jurnal Aplikasi Ekonomi, 5(9), 8-23. 